\title{
Far-western blotting as a solution to the non-specificity of the anti-erythropoietin receptor antibody
}

\author{
BARBORA FECKOVÁ ${ }^{1 *}$, PATRÍCIA KIMÁKOVÁ ${ }^{1 *}$, LENKA ILKOVIČOVÁ ${ }^{1}$, \\ ERIKA SZENTPÉTERIOVÁ ${ }^{1}$, NATAŠA DEBELJAK ${ }^{2}$, ZUZANA SOLÁROVÁ $^{3}$, VERONIKA SAČKOVÁ ${ }^{1}$, \\ MARTINA ŠEMELÁKOVÁ ${ }^{1}$, MANGESH BHIDE $^{4}$ and PETER SOLÁR ${ }^{1}$
}

${ }^{1}$ Department of Cell Biology, Institute of Biology and Ecology, Faculty of Science, Pavol Jozef Šafárik University in Košice, SK-04154 Košice, Slovak Republic; ${ }^{2}$ Institute of Biochemistry, Faculty of Medicine, University of Ljubljana,

SI-1000 Ljubljana, Slovenia; ${ }^{3}$ Institute of Pharmacology, Faculty of Medicine, Pavol Jozef Šafárik University in Košice,

SK-04001 Košice; ${ }^{4}$ Laboratory of Biomedical Microbiology and Immunology,

University of Veterinary Medicine, SK-04181 Košice, Slovak Republic

Received December 3, 2015; Accepted May 24, 2016

DOI: $10.3892 / 01.2016 .4782$

\begin{abstract}
The erythropoietin receptor (EpoR) is a member of the cytokine receptor family. The interaction between erythropoietin (Epo) and EpoR is important for the production and maturation of erythroid cells, resulting in the stimulation of hematopoiesis. The fact that EpoR was also detected in neoplastic cells has opened the question about the relevance of anemia treatment with recombinant Epo in cancer patients. Numerous studies have reported pro-stimulating and anti-apoptotic effects of Epo in cancer cells, thus demonstrating EpoR functionality in these cells. By contrast, a previous study claims the absence of EpoR in tumor cells. This apparent discrepancy is based, according to certain authors, on the use of non-specific anti-EpoR antibodies. With the aim of bypassing the direct detection of EpoR with an anti-EpoR antibody, the present authors propose a far-western blot methodology, which in addition, confirms the interaction of Epo with EpoR. Applying this technique, the presence of EpoR and its interaction with Epo in human ovarian adenocarcinoma A2780 and normal human umbilical vein endothelial cells was confirmed. Furthermore, modified immunoprecipitation of EpoR followed by matrix-assisted laser desorption/ionization-time-of-flight mass spectrometry analysis confirmed a $57 \mathrm{kDa}$ protein as a human Epo-interacting protein in both cell lines.
\end{abstract}

Correspondence to: Professor Peter Solár, Department of Cell Biology, Institute of Biology and Ecology, Faculty of Science, Pavol Jozef Šafárik University in Košice, Šrobárova 2, SK-04154 Košice, Slovak Republic

E-mail: peter.solar@upjs.sk

${ }^{*}$ Contributed equally

Key words: far-western blotting, erythropoietin, erythropoietin receptor, A2780, HUVEC

\section{Introduction}

Erythropoietin (Epo) is a low-molecular weight glycoprotein produced in the kidney by neural peritubular fibroblasts and by the outer medulla $(1,2)$, depending on the amount of oxygen available (3). The Epo hormone facilitates the creation and maturation of erythroid precursors, and stimulates erythropoiesis upon binding to its receptor, known as erythropoietin receptor (EpoR) (4). Recombinant human Epo (rhEpo) is currently available for the treatment of anemia resulted from chronic liver diseases (5) or chronic renal failure (6), and is a good alternative to blood transfusion in cancer-related anemia (7), a frequent symptom of cancer (8) due to chemotherapy (9).

The presence of EpoR has been confirmed in numerous tumor cells, with or without the stimulatory effect of Epo on these cells (10-16). While Epo/EpoR signaling in hematopoietic cells is associated with increased cell proliferation and/or survival, the Epo/EpoR signaling pathway in tumor cells does not always lead to increased cell proliferation, but may alter the sensitivity of cancer cells to therapy (17). The role of Epo and EpoR on growth, survival and therapeutic response in human cancer cells has been previously reviewed by Szenajch et al (17) and Debeljak et al (18).

In this regard, although certain studies did not confirm a direct stimulatory effect of Epo on tumor cells, there is sufficient evidence of this effect on endothelial cell proliferation and/or tumor angiogenesis. Epo induced angiogenesis in murine hepatic tumors (19), accelerated the growth of EpoR-negative Lewis lung carcinoma cells by promoting tumor angiogenesis in vivo (20), stimulated neovascularization in colorectal liver metastases (21), affected glioma vascular endothelial cells and promoted angiogenesis in a paracrine manner (22). Furthermore, Epo can also act directly on glioma stem (23) and breast cancer stem-like cells (24) by activating specific pathways resulting in growth, survival and enhanced tumor progression. Beside the Epo effects on cancer and endothelial cells, there is another direct effect of Epo on 
cancer stem and/or tumor-initiating cells that could explain the enhanced tumor progression and poor survival observed in certain cancer patients treated with Epo (18).

Indeed, Epo-induced signaling in cancer, endothelial and cancer stem cells was associated with the activation of Janus Kinase (JAK)2, JAK3, signal transducer and activator of transcription (STAT)3 and STAT5 (but not with JAK1 or STAT1) (16), Akt phosphorylation (15), extracellular signal-regulated kinase (Erk) phosphorylation (25), human telomerase reverse transcriptase (hTERT) gene transcription by JAK2/STAT5/c-Myc, and hTERT protein phosphorylation by phosphatidylinositol-4,5-bisphosphate 3-kinase/Akt (26). Previously, Swift et al (27) and Elliott et al (28) demonstrated that EpoR is present at no/low level in 66 different tumor cell lines by western blotting with the specific and sensitive anti-EpoR antibody A82 (which is currently not commercially available). In addition, EpoR was undetectable using the A82 antibody in normal and cancerous tissues, and it was undetectable/low in selected breast tumor cell lines (28). According to Elliott et al (28), there is a discrepancy in the detection of EpoR due to the widespread distribution of non-specific antibodies against EpoR.

Far-western blotting is a method for analyzing protein-protein interactions, and could serve as a parallel assay to standard western blot analysis (29). In far-western blotting, the protein samples of interest are subjected to electrophoresis and next immobilized onto a membrane (29). During the transfer, the sodium dodecyl sulfate (SDS) is eliminated, and proteins could re-adopt their three-dimensional structure comprising the interaction site important for probing and binding to non-antibody proteins (29). In contrast to western blot analysis, which detects target proteins with specific antibodies, far-western blotting identifies proteins based on the presence or absence of a binding site to a particular protein probe (30).

To avoid the problem of using 'nonspecific' anti-EpoR antibodies, and to solve the problem of EpoR detection in general, the present authors propose the use of far-western blotting. In this technique, Epo is applied as a second antigen and/or interacting molecule to EpoR, and the anti-Epo antibody allows to bypass the direct detection of EpoR. In addition, this technique enables to determine the EpoR functionality, or at least the capability of Epo to interact with an EpoR of different origin. The present study demonstrated the ability of far-western blotting to detect EpoR on human ovarian adenocarcinoma cells (A2780) and normal human umbilical vein endothelial cells (HUVECs).

\section{Materials and methods}

Cell culture conditions. A2780 cells were obtained from the American Tissue Culture Collection (Manassas, VA, USA). Cells were grown in RPMI-1640 medium with L-glutamine (Gibco; Thermo Fisher Scientific, Inc., Waltham, MA, USA). The medium was supplemented with $10 \%$ fetal bovine serum (Gibco; Thermo Fisher Scientific, Inc.) and antibiotic/antimycotic solution (100 U/ml penicillin, $100 \mu \mathrm{g} / \mathrm{ml}$ streptomycin and $0.25 \mu \mathrm{g} / \mathrm{ml}$ amphotericin B; Invitrogen; Thermo Fisher Scientific, Inc.). The cells were maintained under standard tissue culture conditions at $37^{\circ} \mathrm{C}$ and $5 \%$ $\mathrm{CO}_{2} / 95 \%$ air atmosphere. The number of cells was determined using a ZF Coulter counter (Beckman Coulter, Inc., Brea, CA, USA), and the total cell viability was analyzed by staining with $0.15 \%$ eosin, followed by light microscopy.

HUVECs were isolated, cultured and characterized as previously described $(31,32)$. Cells were cultured on gelatin-coated dishes in cM199 (M199 medium supplemented with $10 \%$ heat-inactivated human serum (PAA; GE Healthcare Life Sciences, Chalfont, UK), 10\% heat-inactivated newborn calf serum (Cambrex Corporation, East Rutherford, NJ, USA), $150 \mu \mathrm{g} / \mathrm{ml}$ crude endothelial cell growth factor (ECGF), $5 \mathrm{IU} / \mathrm{ml}$ heparin, $100 \mathrm{IU} / \mathrm{ml}$ penicillin and $100 \mu \mathrm{g} / \mathrm{ml}$ streptomycin (Sigma-Aldrich, St. Louis, MO, USA) at $37^{\circ} \mathrm{C}$ under a $5 \% \mathrm{CO}_{2} / 95 \%$ air atmosphere. Endothelial cell cultures were washed with medium without ECGF and heparin $24 \mathrm{~h}$ prior to the experiments.

Far-western blotting. A2780 cells and HUVECs were washed twice with ice-cold phosphate-buffered saline (PBS), scraped into lysis buffer [Tris-HCl (pH 7.4), 0.1\% SDS, $10 \%$ glycerol and 100X protease inhibitor cocktail (Sigma-Aldrich)] and incubated for $45 \mathrm{~min}$. Then, lysates were homogenized by sonication on ice for $30 \mathrm{sec}$ at $30 \mathrm{~V}$ (SONOPULS HD 2070; BANDELIN electronic GmbH \& Co. KG, Berlin, Germany). After sonication, lysates were centrifuged at $10,000 \mathrm{x} \mathrm{g}$ for $10 \mathrm{~min}$ at $4^{\circ} \mathrm{C}$, and the supernatants were transferred into $1.5-\mathrm{ml}$ microcentrifuge tubes and quantified according to the Lowry protein assay protocol (Bio-Rad Laboratories, Inc., Hercules, CA, USA). Lysates (100 $\mu$ g each) were then subjected to $12 \%$ SDS-polyacrylamide gel electrophoresis (PAGE) and blotted onto a polyvinylidene fluoride (PVDF) membrane with transfer buffer [3.6 g Tris, $18 \mathrm{~g}$ glycine and $10 \%$ methanol ( $\mathrm{pH} 7.4)]$. The PVDF membrane was blocked with $3 \%$ non-fat milk, followed by 1-h incubation with $15 \mu \mathrm{g}$ rhEpo (40,000 IU/ml; EPREX®); Janssen Biologics B.V., Leiden, The Netherlands) in 1X Tris-buffered saline (TBS) with $0.5 \%$ milk (pH 7.2-7.4). Then, the membrane was washed and incubated overnight with primary anti-Epo antibody (catalog no., MAB2871; 1:1,000; R\&D Systems, Inc., Minneapolis, MN, USA) in $1 \%$ non-fat milk (pH 7.2-7.4). The following day, the membrane was washed two times for $4 \mathrm{~min}$ in TBS with $0.05 \%$ Tween 20 (TBST; pH 7.4), and incubated for $1 \mathrm{~h}$ with secondary horseradish peroxidase (HRP)-conjugated antibody [goat anti-mouse immunoglobulin (Ig) G F(ab')2 fragment; 1:2,000; catalog no., 31436; Pierce; Thermo Fisher Scientific, Inc.] at room temperature (RT). The antibody reactivity was visualized with Pierce ECL Western Blotting Substrate (Thermo Fisher Scientific, Inc.). Bioluminescent signals were detected with ChemiDoc ${ }^{\mathrm{TM}}$ XRS+ and Image Lab 3.0 software (Bio-Rad Laboratories, Inc.) or X-ray films (Roberts Technology Group, Inc., Chalfont, PA, USA). Traditional western blotting for the detection of EpoR with primary anti-Epo $(1: 1,000$; catalog no., MAB2871) and primary goat anti-EpoR antibodies $(1: 1,000$; catalog no., AF-322-PB; R\&D Systems, Inc.) served as controls for far-western blotting detection.

To confirm the affinity between EpoR and rhEpo observed using far-western blotting, a second protein interaction assay where Epo was subjected to $12 \%$ SDS-PAGE and blotted onto a PVDF membrane was performed. The PVDF membrane with rhEpo was then incubated with A2780 or HUVEC cell 
lysates (220 $\mu \mathrm{g}$ each) for $1 \mathrm{~h}$ in $0.5 \%$ milk, followed by overnight incubation with primary anti-EpoR antibody $(1: 1,000$; catalog no., AF-322-PB) in 1\% milk. The following day, the membrane was washed two times for 4 min in TBST ( $\mathrm{pH} 7.4$ ), and then incubated for $1 \mathrm{~h}$ with secondary HRP-conjugated antibody (rabbit anti-goat $\operatorname{IgG} \mathrm{F}\left(\mathrm{ab}^{\prime}\right) 2$ fragment; Pierce; Thermo Fisher Scientific, Inc.) at RT. The antibody reactivity was visualized as mentioned above.

Immunoprecipitation with protein A agarose beads. A total of $80 \mu \mathrm{l}$ agarose beads (Protein A Agarose; Innova Biosciences Ltd., Cambridge, UK) were washed twice with $1 \mathrm{ml}$ ice-cold radioimmunoprecipitation assay (RIPA) buffer (Sigma-Aldrich) and centrifuged for $30 \mathrm{sec}$ at $8,200 \mathrm{x}$ g at $4^{\circ} \mathrm{C}$. Non-specific binding was blocked by incubation of the agarose beads with $2 \%$ bovine serum albumin for $1 \mathrm{~h}$ at RT, followed by two washes with ice-cold RIPA buffer and centrifugation as mentioned above. Both protein A agarose beads with $10 \mu \mathrm{g}$ anti-Epo antibody (MAB 2871) and $22 \mu \mathrm{g}$ rhEpo with the lysate of A2780 cells or HUVECs $(250 \mu \mathrm{g}$ of proteins each) were then incubated for $2 \mathrm{~h}$ on a rotary agitator $(10 \mathrm{rpm}$, $4^{\circ} \mathrm{C}$ ). After two-times washing, the protein A agarose beads/anti-Epo antibody complex was added to the rhEpo/cell lysate complex (EpoR and other proteins) and incubated together for another $1 \mathrm{~h}$ on a rotary agitator $\left(10 \mathrm{rpm}, 4^{\circ} \mathrm{C}\right)$. Upon washing and addition of sample buffer, the complex of protein A agarose beads/anti-Epo/rhEpo/EpoR was boiled for $5 \mathrm{~min}$, centrifuged $\left(10,000 \mathrm{x} \mathrm{g}\right.$ at $24^{\circ} \mathrm{C}$ for $\left.5 \mathrm{~min}\right)$ and subjected to SDS-PAGE (12\%). The gel was washed two times in distilled (d) $\mathrm{H}_{2} \mathrm{O}$ for $5 \mathrm{~min}$, fixed (with $40 \%$ ethanol, $10 \%$ acetic acid and $50 \% \mathrm{dH}_{2} \mathrm{O}$ ) for $1 \mathrm{~h}$, washed again twice in $\mathrm{dH}_{2} \mathrm{O}$ for $10 \mathrm{~min}$, and stained by overnight incubation in $80 \%$ Colloidal Coomassie Blue $(0.1 \%$ Coomassie Brilliant Blue G-250, 2\% orthophosphoric acid and $10 \%$ ammonium sulfate) and $20 \%$ methanol at RT. The following day, the gel was washed in acetic acid (1\%), and the potential EpoR proteins were detached from the gel and analyzed by matrix-assisted laser desorption/ionization (MALDI)-time-of-flight (TOF) mass spectrometry (MS). The detailed protocol of the pull-down assay has been previously described (33). Identification of the proteins observed in the gel was performed by peptide mass fingerprinting, as previously described (34). In short, protein bands were excised and digested as previously described (35). An aliquot of the digested solution was mixed with an aliquot of $\alpha$-cyano-4-hydroxycinnamic acid (Bruker Corporation, Billerica, MA, USA) in 33\% acetonitrile and $0.25 \%$ trifluoroacetic acid. This mixture was then deposited onto a 600- $\mu \mathrm{m}$ AnchorChip (Bruker Corporation), and allowed to dry. MALDI-MS data were obtained in an automated analysis loop using an Ultraflex TOF mass spectrometer (Bruker Corporation). Spectra were acquired in positive-ion mode at $50 \mathrm{~Hz}$ laser frequency, and 100-1,000 individual spectra were averaged. The selected precursor ions were subjected to fragment ion analysis in tandem TOF mode to obtain the corresponding MALDI-MS/MS spectra. Automated analysis of MS data was performed using the Flex Analysis software version 3.0 (Bruker Corporation). MALDI-MS and MALDI-MS/MS data were combined through the BioTools software version 3.2 (Bruker Corporation) to search a non-redundant protein database in the National Center for
Biotechnology Information website (www.ncbi.nlm.nih.gov/), using Mascot software (server version 2.4; Matrix Science, Ltd., London, UK). Each experiment was repeated three times.

Erk1/2 signaling of EpoR in HUVECs. Erk1/2 signaling was monitored in HUVECs only, since the same signaling pathway was previously described in A2780 cells by Solár et al (12). HUVECs were seeded into Petri dishes with M199 medium containing serum, and incubated under the standard conditions described above. HUVECs were washed with serum-free medium $24 \mathrm{~h}$ prior to the experiments, followed by the addition of $5 \mathrm{IU} / \mathrm{ml}$ rhEpo to the experimental group, and the addition of $20 \mathrm{ng}$ vascular endothelial growth factor (VEGF) to the positive control group. After 5, 10, 30 or 60 min of incubation, cells were quickly washed twice with ice-cold PBS, and lysed as mentioned above. HUVEC lysates (30 $\mu \mathrm{g}$ each) were then subjected to SDS-PAGE (12\%), blotted onto PVDF membranes and incubated overnight with primary anti-p44/42 mitogen-activated protein kinase (MAPK; \#9102, 1:1,000; Cell Signaling Technology, Inc., Danvers, MA, USA) or anti-phospho-p44/42 MAPK (\#9101, 1:1,000; Cell Signaling Technology, Inc.) antibodies at $4^{\circ} \mathrm{C}$. The membrane was then reprobed with anti- $\beta$-actin primary antibody (AC-15; $1: 1,000$; catalog no., A5441; Sigma-Aldrich) to detect $\beta$-actin protein, which served as a loading control. The following day, the membrane was washed twice in TBST (pH 7.4) for $4 \mathrm{~min}$, and incubated for $1 \mathrm{~h}$ with secondary HRP-conjugated antibody (goat anti-rabbit IgG F(ab')2 fragment; catalog no., 31461; Pierce; Thermo Fisher Scientific, Inc.) at RT. The antibody reactivity was visualized as mentioned above.

\section{Results}

Far-western blotting was demonstrated to be a simple way to specifically detect EpoR. Far-western blotting avoids the problem of direct identification of EpoR with a potentially non-specific anti-EpoR antibody, and also confirms the interaction of rhEpo with EpoR. Whole proteins of ovarian adenocarcinoma A2780 and normal endothelial HUVECs (including EpoR) were separated and blotted on PVDF membranes, thus representing the antigen for the interaction with rhEpo. The expected EpoR antigen/rhEpo antigen complex was identified with an anti-Epo antibody, followed by traditional western blot detection (Fig. 1A). Two blots without rhEpo served as controls for far-western blot detection. In this regard, one blot was incubated with anti-Epo (Fig. 1B) and the second one with anti-EpoR antibodies (Fig. 1C). Indeed, far-western blotting revealed the same $57-\mathrm{kDa}$ protein in the EpoR/rhEpo/anti-Epo-antibody complex blot and in the control blot with anti-EpoR antibody. In addition, the control blot with anti-Epo antibody detection did not exhibit any protein of $57 \mathrm{kDa}$ in size (Fig. 1B).

Far-western blot detection of rhEpo/EpoR interaction was also confirmed by a second type of interaction assay. For that purpose, rhEpo was blotted onto PVDF membranes, followed by incubation with cell lysates (EpoR) and western blot detection using anti-EpoR antibody. Notably, rhEpo was detected not only by traditional immunoblotting with an anti-Epo antibody (Fig. 2C), but also through rhEpo/EpoR/anti-EpoR-antibody complex, as represented in Fig. 2A and B. In this regard, both 
A

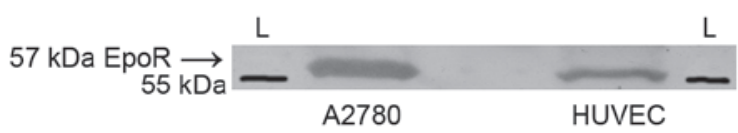

B

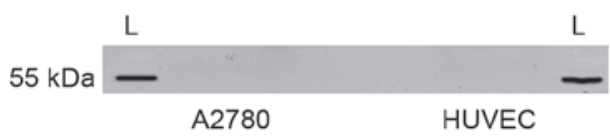

C

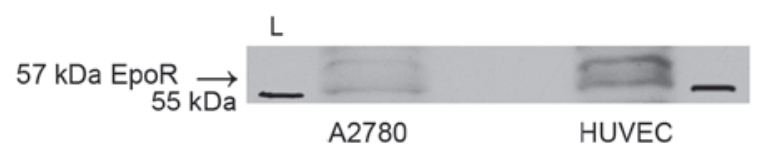

Figure 1. Far-western blotting detection of EpoR. (A) Blots of A2780 and HUVEC lysates (100 $\mu \mathrm{g}$ of proteins each) were incubated with recombinant human Epo, followed by immunodetection with anti-Epo antibody $(5 \mu \mathrm{g})$. Blots of cell lysates incubated with (B) anti-Epo antibody $(5 \mu \mathrm{g})$ and (C) anti-EpoR antibody (1 $\mu \mathrm{g})$ served as controls. Epo, erythropoietin; EpoR, erythropoietin receptor; HUVEC, human umbilical vein endothelial cell; L, ladder.
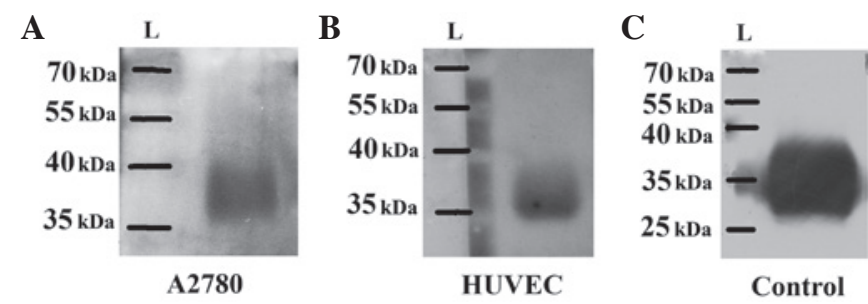

Figure 2. Confirmation of rhEpo/EpoR interaction. Blots with $12 \mu \mathrm{g}$ rhEpo were incubated with the cell lysates of (A) A2780 and (B) HUVECs (220 $\mu \mathrm{g}$ of proteins each), followed by immunodetection with an anti-EpoR antibody $(1 \mu \mathrm{g})$. (C) Blot with $12 \mu \mathrm{g}$ rhEpo was incubated only with anti-Epo antibody $(5 \mu \mathrm{g})$ and served as a positive control. Epo, erythropoietin; rhEpo, recombinant human erythropoietin; EpoR, erythropoietin receptor; HUVEC, human umbilical vein endothelial cell; L, ladder.

A2780 cells (Fig. 2A) and HUVECs (Fig. 2B) exhibited a clear interaction of their EpoR protein with rhEpo.

For further verification of the aforementioned rhEpo/EpoR interaction, immunoprecipitation with protein A agarose beads was applied. Independently incubated anti-Epo antibody with protein A agarose beads and cell lysates with rhEpo were subsequently mixed and incubated together, and the resulting protein complex was separated on SDS-PAGE and stained with Coomassie Blue. While the control groups did not reveal any interaction between the protein A agarose beads and the proteins in the cell lysates or the added rhEpo (data not shown), the anti-Epo antibody captured on the protein A agarose beads did interact with $39-, 57-$ and $>57-\mathrm{kDa}$ proteins (Fig. 3). Only the $57-\mathrm{kDa}$ protein was detached from the gel, subjected to MALDI-TOF analysis and verified as Epo-interacting EpoR $(\mathrm{P}<0.014)$, thus corresponding to the full-length EpoR. The details of MS analysis and Mascot search are as follows: number of peptides matched by MS, 6; number of peptides matched by MS/MS, 2; score, 73; sequence coverage, 53\%; accession no. matched-gil6137384 (www.ncbi.nlm.nih.gov/protein/gi\%7C6137384).

Since EpoR signaling in A2780 cells has been previously published (12), the present study provided evidence of the
A

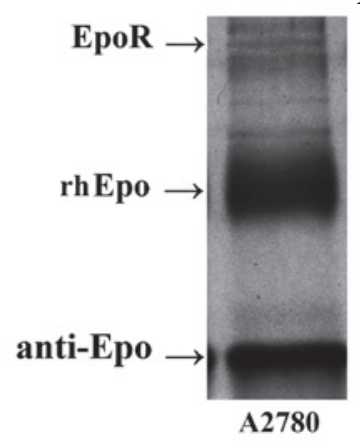

B

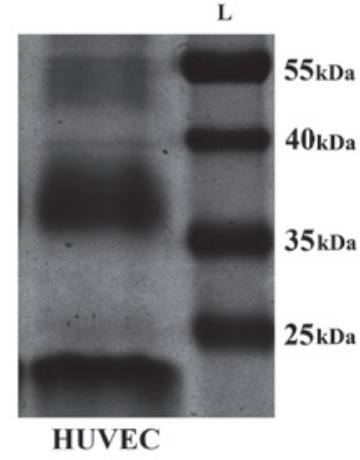

Figure 3. Confirmation of rhEpo/EpoR interaction by immunoprecipitation with protein A agarose beads. The complexes of $80 \mu 1$ protein A agarose beads/anti-Epo/rhEpo/EpoR of (A) A2780 and (B) HUVEC lysates (220 $\mu \mathrm{g}$ of proteins each) were separated on the gel and stained with Coomassie Blue. Black dots indicate the localization of EpoR. Epo, erythropoietin; rhEpo, recombinant human erythropoietin; EpoR, erythropoietin receptor; HUVEC, human umbilical vein endothelial cell; L, ladder.

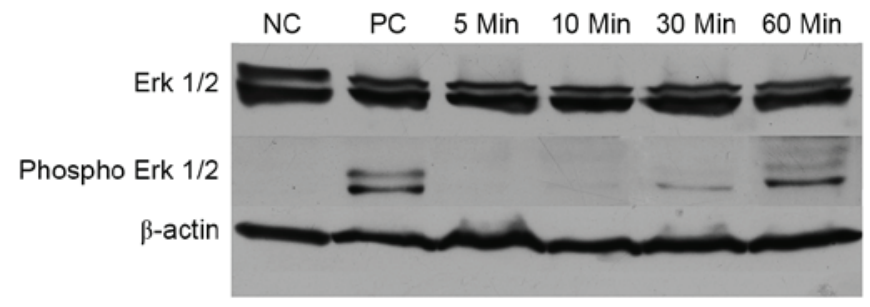

Figure 4. Epo induced Erk1/2 signaling in HUVECs. Western blot analysis of Erk1/2 and phospho-Erk1/2 proteins in HUVECs at 5, 10,30 and 60 min after incubation with $5 \mathrm{IU} / \mathrm{ml}$ rhEpo. HUVECs stimulated with $20 \mathrm{ng}$ rhVEGF were used as a positive control, while HUVECs without rhEpo or rhVEGF stimulation were used as a negative control. NC, negative control; PC, positive control; Erk, extracellular signal-regulated kinase; HUVEC, human umbilical vein endothelial cell; Epo, erythropoietin; rhEpo, recombinant human erythropoietin; rhVEGF, recombinant human vascular endothelial growth factor.

functionality of the rhEpo/EpoR complex on HUVECs. These cells were starved overnight, and incubated with rhEpo for 5-60 min or with rhVEGF (positive control) for $10 \mathrm{~min}$, and then processed for western blot analysis. rhEpo at a concentration of $5 \mathrm{IU} / \mathrm{ml}$ increased the phosphorylation of Erk1/2 at $30 \mathrm{~min}$, and reached the maximum at $60 \mathrm{~min}$ after the addition of rhEpo. Furthermore, the phosphorylation of Erk1/2 at $60 \mathrm{~min}$ following rhEpo addition achieved the same intensity than phospho-Erk1/2 induced by recombinant VEGF (positive control) (Fig. 4).

\section{Discussion}

Hematopoiesis is an essential body process that supplies new blood cells (36). Following the identification of Epo as a main stimulator of this process, research has focused more recently on its receptor, EpoR (37). Epo stimulates cells through its interaction with EpoR on the cell surface (12). EpoR has been identified not only in hematopoietic cells, but also in multiple non-hematopoietic cells and tissues, where autocrine, paracrine and endocrine actions have been proposed for EpoR (38). Different types of tumors and cell lines have been found to express EpoR messenger (m)RNA transcripts, which may be 
translated into full-length, soluble or other truncated forms of EpoR (39). EpoR expression has been demonstrated in a panel of 29 tumor cell lines, including 18 adherent cell lines (40). In this regard, several groups have reported the presence of EpoR also in ovarian cancer cell lines $(12,27,40-42)$, but disagreements, particularly in the proportion of mRNA and the amount of surface EpoR protein, were reported. Furthermore, Ribatti et al (43) demonstrated the presence of EpoR in HUVECs and EA.hy926 hematopoietic cells (a cell fusion derived of HUVECs and lung carcinoma A549 cells). However, Sinclair et al (44) claim that numerous researchers have selected non-specific anti-EpoR antibodies for their studies, thus producing false-positive results (45). Therefore, the presence of EpoR protein in different normal and cancer cell lines is questionable. To avoid such false positivity and to additionally demonstrate that EpoR is the Epo-interacting protein, the present authors suggest to use far-western blotting, as this technique allows bypassing of the direct detection of EpoR. This method requires both rhEpo as well as an specific antibody against rhEpo, which can be verified through detection of blotted rhEpo by traditional western blotting (used as a positive control in the present study). Indeed, besides the demonstration of Epo/EpoR interaction, far-western blotting allowed to confirm in the current case the presence of EpoR protein in human ovarian adenocarcinoma A2780 cells and in normal HUVECs. In this regard, Sinclair et al (44) detected 59-kDa EpoR in HUVECs using the primary A82 anti-EpoR antibody, but the concentration of EpoR homodimers per HUVEC was low, and the rhEpo/EpoR interaction in these cells was absent. Notably, although the present western blot results with the primary anti-EpoR antibody AF322-PB (used as far-western blotting control) revealed 57- and 59-kDa EpoR proteins, only the $57-\mathrm{kDa}$ protein was confirmed by far-western blotting and immunoprecipitation with protein $\mathrm{A}$ agarose beads, followed by MALDI-TOF verification, as the rhEpo-interacting EpoR protein.

The present authors have previously investigated the functionality of EpoR in A2780 cells through rhEpo-induced signaling transduction and its modification after the addition of soluble EpoR or specific lentiviral-mediated small hairpin (sh)RNA silencing of EpoR expression (12). Both methods resulted in the deprivation of Erk1/2 signaling induced by rhEpo treatment in A2780 cells. In addition, EpoR silencing reduced the protein levels of JAK2 and STAT5 in shRNA-treated cells in comparison with non-targeted (NT) shRNA control cells. Although the addition of rhEpo did not stimulate A2780 cell proliferation, downregulation of EpoR expression by shRNA resulted in reduced cell proliferation when monitored at 48, 72 and $96 \mathrm{~h}$ after seeding, compared with NTshRNA control-treated and normal A2780 cells (12). Despite the higher levels of EpoR transcripts detected in HUVECs, Sinclair et al (44) did not find any significant Erk1/2 or Akt phosphorylation after rhEpo stimulation. The interaction of rhEpo with EpoR of vascular endothelial cells was declared by increased intracellular levels of free calcium and tyrosine phosphorylation of STAT5 (46-48). In the present study, overnight-starved HUVECs incubated with rhEpo showed increased Erk1/2 phosphorylation at $30 \mathrm{~min}$ after the addition of rhEpo at a concentration of $5 \mathrm{IU} / \mathrm{ml}$. Indeed, the phosphorylation of Erk1/2 at $60 \mathrm{~min}$ after rhEpo addition achieved the same intensity than the phospho-Erk1/2 signal induced by recombinant VEGF protein.

In conclusion, the present study confirmed the presence and the interaction of rhEpo/EpoR using the far-western blotting technique in both human ovarian adenocarcinoma A2780 cells as well as in normal HUVECs. Furthermore, modified immunoprecipitation of EpoR followed by MALDI-TOF MS analysis confirmed the $57-\mathrm{kDa}$ protein as the human Epo-interacting EpoR protein in both cell lines.

\section{Acknowledgements}

The present study was supported by the Scientific Grant Agency of the Ministry of Education, Science, Research and Sport of the Slovak Republic (Bratislava, Slovak Republic; grant no. VEGA 1/0394/15) and by internal scientific grants from Pavol Jozef Šafárik University in Košice (Košice, Slovak Republic; grant nos. VVGS-2014-190 and VVGS-2014-220).

\section{References}

1. Lacombe C, Da Silva JL, Bruneval P, Fournier JG, Wendling F, Casadevall N, Camilleri JP, Bariety J, Varet B and Tambourin P: Peritubular cells are the site of erythropoietin synthesis in the murine hypoxic kidney. J Clin Invest 81: 620-623, 1988.

2. Koury ST, Bondurant MC, Semenza GL and Koury MJ: The use of in situ hybridization to study erythropoietin gene expression in murine kidney and liver. Microsc Res Tech 25: 29-39, 1993.

3. Frede S, Freitag P, Geuting L, Konietzny R and Fandrey J: Oxygen-regulated expression of the erythropoietin gene in the human renal cell line REPC. Blood 117: 4905-4914, 2011.

4. Lodish H, Flygare J and Chou S: From stem cell to erythroblast: Regulation of red cell production at multiple levels by multiple hormones. IUBMB Life 62: 492-496, 2010.

5. Bruno CM, Neri S, Sciacca C, Bertino G, Di Prima P, Cilio D, Pellicano R, Caruso L and Cristaldi R: Plasma erythropoietin levels in anaemic and non-anaemic patients with chronic liver diseases. World J Gastroenterol 10: 1353-1356, 2004.

6. Pinevich AJ and Petersen J: Erythropoietin therapy in patients with chronic renal failure. West J Med 157: 154-157, 1992.

7. Bohlius J, Weingart O, Trelle S and Engert A: Cancer-related anemia and recombinant human erythropoietin-an updated overview. Nat Clin Pract Oncol 3: 152-164, 2006

8. Cella D: The functional assessment of cancer therapy-anemia (FACT-An) Scale: A new tool for the assessment of outcomes in cancer anemia and fatigue. Semin Hematol 34 (3 Suppl 2): S13-S19, 1997.

9. Demetri GD, Kris M, Wade J, Degos L and Cella D: Quality-of-life benefit in chemotherapy patients treated with epoetin alfa is independent of disease response or tumor type: Results from a prospective community oncology study. Procrit study group. J Clin Oncol 16: 3412-3425, 1998.

10. Jeong JY, Hoxhaj G, Socha AL, Sytkowski AJ and Feldman L: An erythropoietin autocrine/paracrine axis modulates the growth and survival of human prostate cancer cells. Mol Cancer Res 7: 1150-1157, 2009.

11. Wu P, Zhang N, Wang X, Zhang C, Li T, Ning X and Gong K: The erythropoietin/erythropoietin receptor signaling pathway promotes growth and invasion abilities in human renal carcinoma cells. PLoS One 7: e45122, 2012.

12. Solár P, Hrčková G, Varinská L, Solárová Z, Kriška J, Uhrínová I, Kello M, Mojžiš J, Fedoročko P and Sytkowski AJ: Location and the functionality of erythropoietin receptor(s) in A2780 cells. Oncol Rep 28: 141-146, 2012.

13. Miyake M, Goodison S, Lawton A, Zhang G, Gomes-Giacoia E and Rosser CJ: Erythropoietin is a JAK2 and ERK1/2 effector that can promote renal tumor cell proliferation under hypoxic conditions. J Hematol Oncol 6: 65, 2013.

14. Trost N, Stepisnik T, Berne S, Pucer A, Petan T, Komel R and Debeljak N: Recombinant human erythropoietin alters gene expression and stimulates proliferation of MCF-7 breast cancer cells. Radiol Oncol 47: 382-389, 2013. 
15. Abhold E, Rahimy E, Wang-Rodriguez J, Blair KJ, Yu MA, Brumund KT, Weisman RA and Ongkeko WM: Recombinant human erythropoietin promotes the acquisition of a malignant phenotype in head and neck squamous cell carcinoma cell lines in vitro. BMC Res Notes 4: 553, 2011.

16. Lopez TV, Lappin TR, Maxwell P, Shi Z, Lopez-Marure R, Aguilar C and Rocha-Zavaleta L: Autocrine/paracrine erythropoietin signalling promotes JAK/STAT-dependent proliferation of human cervical cancer cells. Int J Cancer 129: 2566-2576, 2011.

17. Szenajch J, Wcislo G, Jeong JY, Szczylik C and Feldman L: The role of erythropoietin and its receptor in growth, survival and therapeutic response of human tumor cells From clinic to bench-a critical review. Biochim Biophys Acta 1806: 82-95, 2010.

18. Debeljak N, Solár P and Sytkowski AJ: Erythropoietin and cancer: The unintended consequences of anemia correction. Front Immunol 5: 563, 2014.

19. Nakamatsu K, Nishimura Y, Suzuki M, Kanamori S, Maenishi O and Yasuda Y: Erythropoietin/erythropoietin-receptor system as an angiogenic factor in chemically induced murine hepatic tumors. Int J Clin Oncol 9: 184-188, 2004.

20. Okazaki T, Ebihara S, Asada M, Yamanda S, Niu K and Arai $\mathrm{H}$ : Erythropoietin promotes the growth of tumors lacking its receptor and decreases survival of tumor-bearing mice by enhancing angiogenesis. Neoplasia 10: 932-939, 2008.

21. Rupertus K, Senger S, Menger MD, Schilling MK and Kollmar O: Darbepoetin- $\alpha$ promotes neovascularization and cel proliferation in established colorectal liver metastases. J Surg Res 176: 517-523, 2012.

22. Nico B, Annese T, Guidolin D, Finato N, Crivellato E and Ribatti D: Epo is involved in angiogenesis in human glioma. J Neurooncol 102: 51-58, 2011

23. Cao Y, Lathia JD, Eyler CE, Wu Q, Li Z, Wang H, McLendon RE, Hjelmeland $\mathrm{AB}$ and Rich JN: Erythropoietin receptor signaling through STAT3 is required for glioma stem cell maintenance. Genes Cancer 1: 50-61, 2010.

24. Todaro M, Turdo A, Bartucci M, Iovino F, Dattilo R, Biffoni M, Stassi G, Federici G, De Maria R and Zeuner A: Erythropoietin activates cell survival pathways in breast cancer stem-like cells to protect them from chemotherapy. Cancer Res 73: 6393-6400, 2013

25. Pérés EA, Valable S, Guillamo JS, Marteau L, Bernaudin JF, Roussel S, Lechapt-Zalcman E, Bernaudin M and Petit E: Targeting the erythropoietin receptor on glioma cells reduces tumour growth. Exp Cell Res 317: 2321-2332, 2011.

26. Akiyama M, Kawano T, Mikami-Terao Y, Agawa-Ohta M, Yamada $\mathrm{O}$, Ida $\mathrm{H}$ and Yamada $\mathrm{H}$ : Erythropoietin activates telomerase through transcriptional and posttranscriptional regulation in human erythroleukemic JAS-REN-A cells. Leuk Res 35: 416-418, 2011.

27. Swift S, Ellison AR, Kassner P, McCaffery I, Rossi J, Sinclair AM, Begley CG and Elliott S: Absence of functional EpoR expression in human tumor cell lines. Blood 115: 4254-4263, 2010.

28. Elliott S, Swift S, Busse L, Scully S, Van G, Rossi J and Johnson C: Epo receptors are not detectable in primary human tumor tissue samples. PLoS One 8: e68083, 2013.

29. Jadwin JA, Mayer BJ and Machida K: Detection and quantification of protein-protein interactions by far-western blotting. Methods Mol Biol 1312: 379-398, 2015.

30. Elliott S, Busse L, McCaffery I, Rossi J, Sinclair A, Spahr C, Swift $S$ and Begley CG: Identification of a sensitive anti-erythropoietin receptor monoclonal antibody allows detection of low levels of EpoR in cells. J Immunol Methods 352: 126-139, 2010.

31. Van Hinsbergh VW, Sprengers ED and Kooistra T: Effect of thrombin on the production of plasminogen activators and PA inhibitor-1 by human foreskin microvascular endothelial cells Thromb Haemost 57: 148-153, 1987.
32. Defilippi P, van Hinsbergh V, Bertolotto A, Rossino P, Silengo L and Tarone G: Differential distribution and modulation of expression of alpha 1/beta 1 integrin on human endothelial cells. J Cell Biol 114: 855-863, 1991.

33. Mlynarcik P, Bencurova E, Madar M, Mucha R, Pulzova L, Hresko $\mathrm{S}$ and Bhide M: Development of simple and rapid elution methods for proteins from various affinity beads for their direct MALDI-TOF downstream application. J Proteomics 75: 4529-4535, 2012.

34. Bhide MR, Escudero R, Camafeita E, Gil H, Jado I and Anda P: Complement factor $\mathrm{H}$ binding by different Lyme disease and relapsing fever Borrelia in animals and human. BMC Res Notes 2: 134, 2009.

35. Shevchenko A, Tomas H, Havlis J, Olsen JV and Mann M: In-gel digestion for mass spectrometric characterization of proteins and proteomes. Nat Protoc 1: 2856-2860, 2006.

36. Till JE and McCulloch E: A direct measurement of the radiation sensitivity of normal mouse bone marrow cells. Radiat Res 14: 213-222, 1961.

37. Bonsdorf $\mathrm{E}$ and Jalavisto E: A humoral mechanism in anoxic erythrocytosis. Acta Physiol Scand 16: 150-170, 1948.

38. Arcasoy MO: The non-haematopoietic biological effects of erythropoietin. Br J Haematol 141: 14-31, 2008.

39. Arcasoy MO, Jiang X and Haroon ZA: Expression of erythropoietin receptor splice variants in human cancer. Biochem Biophys Res Commun 307: 999-1007, 2003.

40. Miller CP, Lowe KA, Valliant-Saunders K, Kaiser JF, Mattern D, Urban N, Henke M and Blau CA: Evaluating erythropoietin-associated tumor progression using archival tissues from a phase III clinical trial. Stem Cells 27: 2353-2361, 2009.

41. Jeong JY, Feldman L, Solar P, Szenajch J and Sytkowski AJ: Characterization of erythropoietin receptor and erythropoietin expression and function in human ovarian cancer cells. Int J Cancer 122: 274-280, 2008

42. Paragh G, Kumar SM, Rakosy Z, Choi SC, Xu X and Acs G: RNA interference-mediated inhibition of erythropoietin receptor expression suppresses tumor growth and invasiveness in A2780 human ovarian carcinoma cells. Am J Pathol 174: 1504-1514, 2009.

43. Ribatti D, Presta M, Vacca A, Ria R, Giuliani R, Dell'Era P, Nico B, Roncali L and Dammacco F: Human erythropoietin induces a pro-angiogenic phenotype in cultured endothelial cells and stimulates neovascularization in vivo. Blood 93: 2627-2636, 1999.

44. Sinclair AM, Coxon A, McCaffery I, Kaufman S, Paweletz K, Liu L, Busse L, Swift S, Elliott S and Begley CG: Functional erythropoietin receptor is undetectable in endothelial, cardiac, neuronal, and renal cells. Blood 115: 4264-4272, 2010.

45. Laugsch M, Metzen E, Svensson T, Depping R and Jelkmann W: Lack of functional erythropoietin receptors of cancer cell lines. Int J Cancer 122: 1005-1011, 2008.

46. Vogel V, Kramer HJ, Bäcker A, Meyer-Lehnert H, Jelkmann W and Fandrey J: Effects of erythropoietin on endothelin-1 synthesis and the cellular calcium messenger system in vascular endothelial cells. Am J Hypertens 10: 289-296, 1997.

47. Haller H, Christel C, Dannenberg L, Thiele P, Lindschau C and Luft FC: Signal transduction of erythropoietin in endothelial cells. Kidney Int 50: 481-488, 1996

48. Janmaat ML, Heerkens JL, de Bruin AM, Klous A, de Waard V and de Vries CJ: Erythropoietin accelerates smooth muscle cell-rich vascular lesion formation in mice through endothelial cell activation involving enhanced PDGF-BB release. Blood 115: 1453-1460, 2010 